\title{
Erratum to delivery of vascular endothelial growth factor (VEGFC) via engineered exosomes improves lymphedema
}

\section{Editorial Office}

Annals of Translational Medicine

Correspondence to: Editorial Office. Annals of Translational Medicine. Email: editor@atmjournal.org.

Submitted Jul 07, 2021. Accepted for publication Jul 21, 2021.

doi: $10.21037 /$ atm-2021-22

View this article at: https://dx.doi.org/10.21037/atm-2021-22

Erratum to: Ann Transl Med 2020;8:1498

In the article entitled "Delivery of vascular endothelial growth factor (VEGFC) via engineered exosomes improves lymphedema" (1), there is an error of the funding information.

The funding statement "This work was financially supported by the National Natural Science Foundation of China (8187020594)" should be corrected as "The project was supported by the National Natural Science Foundation of China (No. 81873530)."

Click here to view the updated version of the article.

Open Access Statement: This is an Open Access article distributed in accordance with the Creative Commons AttributionNonCommercial-NoDerivs 4.0 International License (CC BY-NC-ND 4.0), which permits the non-commercial replication and distribution of the article with the strict proviso that no changes or edits are made and the original work is properly cited (including links to both the formal publication through the relevant DOI and the license). See: https://creativecommons.org/ licenses/by-nc-nd/4.0/.

\section{References}

1. Li B, Yang J, Wang R, et al. Delivery of vascular endothelial growth factor (VEGFC) via engineered exosomes improves lymphedema. Ann Transl Med 2020;8:1498.

Cite this article as: Editorial Office. Erratum to delivery of vascular endothelial growth factor (VEGFC) via engineered exosomes improves lymphedema. Ann Transl Med 2021;9(15):1281. doi: $10.21037 / \mathrm{atm}-2021-22$ 